\title{
Ideal Protein Concept in Broiler Starter Phase (0-28 Days) Using Low-Protein Diets Supplemented with the Most Limiting Essential Amino Acids
}

\author{
A. O. Fasuyi ${ }^{1 *}$, T. A. Oluwasola ${ }^{1}$, J. O. Ojo ${ }^{1}$, S. S. Fagbuaro ${ }^{1}$ and A. S. Abioye ${ }^{1}$ \\ ${ }^{1}$ Department of Animal Production and Health Sciences, Faculty of Agricultural Sciences, \\ Ekiti State University, Ado-Ekiti, Nigeria.
}

\begin{abstract}
Authors' contributions
This work was carried out in collaboration between all authors. Author AOF designed the study with technical inputs from authors TAO, JOO and SSF. The research study was carried out under the supervision of all authors excluding author ASA who was an undergraduate student working on his final year project work. The authors jointly did the statistical analyses, wrote the results and discussed the findings of the study. All authors read and approved the final manuscript.

Article Information

DOI: $10.9734 / J E A I / 2017 / 36256$

Editor(s):

(1) Hugo Daniel Solana, Department of Biological Science, National University of Central Buenos Aires, Argentina. (2) Anita Biesiada, Department of Horticulture, Wroclaw University of Environmental and Life Sciences, Poland.

Reviewers:

(1) Sarzamin Khan, The University of Agriculture Peshawar, Pakistan. (2) David Latshaw, Ohio State University, United States. (3) Akapo Olajetemi Abiola, Federal University of Agriculture Abeokuta, Nigeria. Complete Peer review History: http://www.sciencedomain.org/review-history/21389
\end{abstract}

Original Research Article

Received $20^{\text {th }}$ August 2017

Accepted $3^{\text {rd }}$ October 2017

Published $13^{\text {th }}$ October 2017

\begin{abstract}
Ideal protein concept was tested by evaluating the growth performance and nitrogen utilization of broiler birds (0-28 days). The most limiting essential amino acids (EAAs), L-Lysine, DL-Methionine, L-Tryptophan and L-Threonine were used in supplementing broiler diets in which crude protein levels were reduced across the diets. Crude protein (CP) levels varied from $23.0 \%$ in the control diet with the addition of the most limiting EAAs to other diets. Diet 6 had the lowest CP of $11.0 \%$. Growth parameters and nitrogen retention were investigated and data obtained were analysed statistically using Minitab (Version 16). The feed intake reduced significantly $(P<0.05)$ across the diets with the highest value of $58.68 \pm 0.03 \mathrm{~g} / \mathrm{b} / \mathrm{d}$ obtained for birds on the control diet of $23.0 \% \mathrm{CP}$ and the lowest FI value obtained for birds on $11.0 \% \mathrm{CP}$ diet with EAAs supplementation. The average weight gain (WG) also had the highest value of $33.47 \pm 0.03 \mathrm{~g} / \mathrm{b} / \mathrm{d}$ for birds on the conventional control diet. Birds
\end{abstract}

${ }^{*}$ Corresponding author: E-mail: ayodeji.fasuyi@eksu.edu.ng; 
on the least CP inclusion of $11.0 \%$ (diet 6 ) had the lowest average WG of $13.35 \pm 0.87 \mathrm{~g} / \mathrm{b} / \mathrm{d}$. Expectedly, the feed conversion ratio (FCR) had the best and lowest value of $1.75 \pm 0.01$ for birds on the conventional control diet and the lowest for birds on the $11.0 \%$ CP (diet 6) at $3.31 \pm 0.20$. The protein efficiency ratio (PER) had the best and highest value of $3.23 \pm 0.06$ for birds on the $14.0 \%$ low crude protein diet. The average nitrogen retention (NR) had the highest significant value of $0.78 \pm 0.02 \mathrm{gN}$ for birds on the $11.0 \% \mathrm{CP}$ diet (diet 6). The lowest significantly different $(P<0.05)$ AND value of $45.65 \pm 0.79 \%$ was obtained for birds on $11.0 \%$ low CP diet supplemented with EAAs. Birds on conventional control diet in which $23.0 \% \mathrm{CP}$ was used with an animal protein source and birds on $20.0 \%$ CP with EAAs supplementation had the best similar FCR of $1.75 \pm 0.01$ and $1.90 \pm 0.02$, respectively. Crude protein can be reduced by 3 percentage points from the conventional $23.0 \%$ (NRC 1994 recommendation) to $20.0 \%$ CP without any detrimental effects on the growth performance indices of broiler starter birds (1-28 days).Protein efficiency ratios were better for growing birds on EAAs supplementation.

Keywords: Percentage point reduction of crude protein; essential amino acids; low crude protein diets.

\section{INTRODUCTION}

The concept of ideal protein has been proposed more than 50 years ago and is still very relevant. The diet of poultry is supplemented with synthetic amino acids to enhance production. Researchers have reported several benefits of amino acid supplementation as follows: (1) reducing cost in production, (2) producing the optimal balance of essential amino acids that presumably enhances growth, maximizes edible meat yield, reduces carcass fat and enables precise selection of progeny for breeding programs, and (3) balancing an animal's nutrient intake to conserve resources and minimize wastes $[1,2,3,4,5,6]$.

Ideal protein concept is often used to express animals' amino acid requirements. It is becoming increasingly clear to broiler nutritionists that the understanding of the value of formulating on a digestible amino acid basis using crystalline amino acids such as DL-Methionine, L-Lysine and L-Threonine and other limiting essential amino acids is appropriate.

Since the ultimate goal of poultry nutritionists is to reduce feed costs, while maximizing the broilers' efficient use of dietary protein and other nutrients, formulating on a digestible amino acid basis and using crystalline amino acids allows the nutritionists to balance dietary amino acids with the ingredients at their disposal, and minimize feed costs via the reduction in dietary soybean meal, dried distillers grains, and animal by-product use. Despite these tools, the nutritionist continually faces challenges when it comes to advances in broiler genetics such as intense selection for greater feed intake, growth, feed conversion and/or higher breast meat yield. While these selection criteria may seem minor, some of the selections just mentioned very likely affect the amino acid requirements of broilers, specifically digestible lysine (dLys) and digestible threonine (dThr). Amino acid (AA) supplements (Met, Lys, and Thr) are used in commercial broiler diets to reduce diet cost and decrease nitrogen excretion without compromising performance objectives.

Since it is becoming trendy in the commercial poultry production to separate the broiler phases into starter and finisher phases with the two phases having high purchasing premiums from retailers, this study has been designed to investigate the ideal protein concept by evaluating the growth performance and nitrogen utilization of broiler birds at between day 1 and day 28.

\section{MATERIALS AND METHODS}

\subsection{Experimental Site}

The experiment was carried out in the Poultry Unit of the Teaching and Research Farm ( $T$ \& RF) of Ekiti State University, Ado-Ekiti with geographical coordinates of $7^{\circ} 38^{\prime} 0^{\prime \prime}$ North, $5^{\circ} 13^{\prime}$ 0 " East The T \&RF and a tropical humid climate with distinct wet and dry seasons. The rainy season spans over seven months starting from March/early April to October with a dry spell in August. Temperature in this area is fairly uniform throughout the year with little deviation from the mean annual of $27^{\circ} \mathrm{C}$. The topography is moderately sloppy with the highest point having the slope of not greater than $6 \%$. The main vegetation is grass but activities like bush fallowing influences vegetation. The experiment was carried out between March and June, 2016. Further laboratory analyses were carried out at the Animal Production and Health Sciences 
Laboratories of Ekiti State University and The Federal University of Technology, Akure.

\subsection{Site Preparation}

Prior to the arrival of broiler chicks, the poultry house and metabolism cage were thoroughly washed and fumigated with diskol (a disinfectant containing $4 \%$ benzalkonium chloride, 3\% glutaraldehyde, 14\% formaldehyde, stabilizers, antioxidants and activators). The house was covered to prevent heat loss and brooding equipment installed.

\subsection{Sourcing of Pharmaceutical Feed- Grade Amino Acids}

Feed-grade L-Lysine, L-Tryptophan and LThreonine amino acids were ordered from
Ajinomoto Animal Nutrition, Ajinomoto North America, Inc., 4020 Ajinomoto Drive, Raleigh, USA. Pharmaceutical-grade amino acids are reputed to be between $99 \%$ and $100 \%$ pure. Ajinomoto amino acids are used for multiple nutritional applications, including intravenous solutions, infant and pediatric formulas and other dietary supplements. They are on the list of U.S. Food and Drug Administration (FDA) having complied with the current Good Manufacturing Practice (cGMP). Ajinomoto is a research leader in the nutritional physiology of amino acids, generating knowledge and understanding of the properties and behavior of amino acids, and creating even more medical and nutritional applications. DL-Methionine was purchased locally from a reputable feed mill in Akure, Ondo State, Nigeria.

The technical information on the feed grade amino acids are as follows:

\section{L-Lysine Monohydrochloride (feed grade, $78.8 \%$ )}

\section{Commercial Guarantee:}

L-Lysine content

Physical data:

Chemical formula

Molecular weight $_{1}$

Appearance

Purity (L-lysine base)

Dry matter

Bulky Density

Total nitrogen

Chloride (Cl)

Crude protein $\left(\% 16 \mathrm{~g}-\mathrm{N}_{1}\right)$

Calculated energy

Poultry, ME

Stability:

Shelf life

Pelleting stability

\section{L-Threonine (feed grade, $\mathbf{7 8 . 8 \%}$}

Commercial Guarantee:

L-Threonine content

Physical Data:

Chemical formula

Molecular weight

Appearance

Content

Dry matter

Bulk Density

Total nitrigen 1

Crude protein $\left(\% / 16 g-\mathrm{N}_{1}\right)$

Calculated energy: Poultry, ME

Stability:

Shelf life (unopened packaging)

Pelleting stability
$78.8 \%$ minimum

$\mathrm{C}_{6} \mathrm{H}_{14} \mathrm{~N}_{2} \mathrm{O}_{2} \mathrm{HCL}$

182.65

Yellowish-white, crystalline powder

$78.8 \%$ (on as-is basis); $80.0 \%$ (dry matter basis)

$98.5 \%$ (minimum)

0.55 to $0.65 \mathrm{grams} / \mathrm{cm}^{3}$ ( 34.3 to $40.5 \mathrm{lbs} / \mathrm{ft}^{3}$ )

$15.12 \%$ (on an as-is basis)

$19.40 \%$ (on an as-is basis)

$94.40 \%$ (on an as-is basis)

$4,120(\mathrm{kcal} / \mathrm{kg})$

$1870(\mathrm{kcal} / \mathrm{lb})$

3 years (25 kg Bags); 1year (1,000 kg Totes)

stable under commercial pelleting conditions

$98.5 \%$ minimum

$\mathrm{C}_{4} \mathrm{H}_{9} \mathrm{NO}_{3}$

119.12

white to off- white crystalline or granule

$98.0 \%$ (on an as-is basis); $98.5 \%$ (dry matter basis)

$99.5 \%$ (minimum)

0.6 to $0.7 \mathrm{grams} / \mathrm{cm}^{3}$ (37.4 to $43.7 \mathrm{lbs} . / \mathrm{ft}^{3}$ )

$11.52 \%$ (on an-is basis)

$72.03 \%$ (on an as-is basis)

$3,570(\mathrm{kcal} / \mathrm{kg}) \quad 1,619(\mathrm{kcal} / \mathrm{lb})$

3 years (25 kg Bags); 1year (1,000 kg Totes)

stable under commercial pelleting conditions 

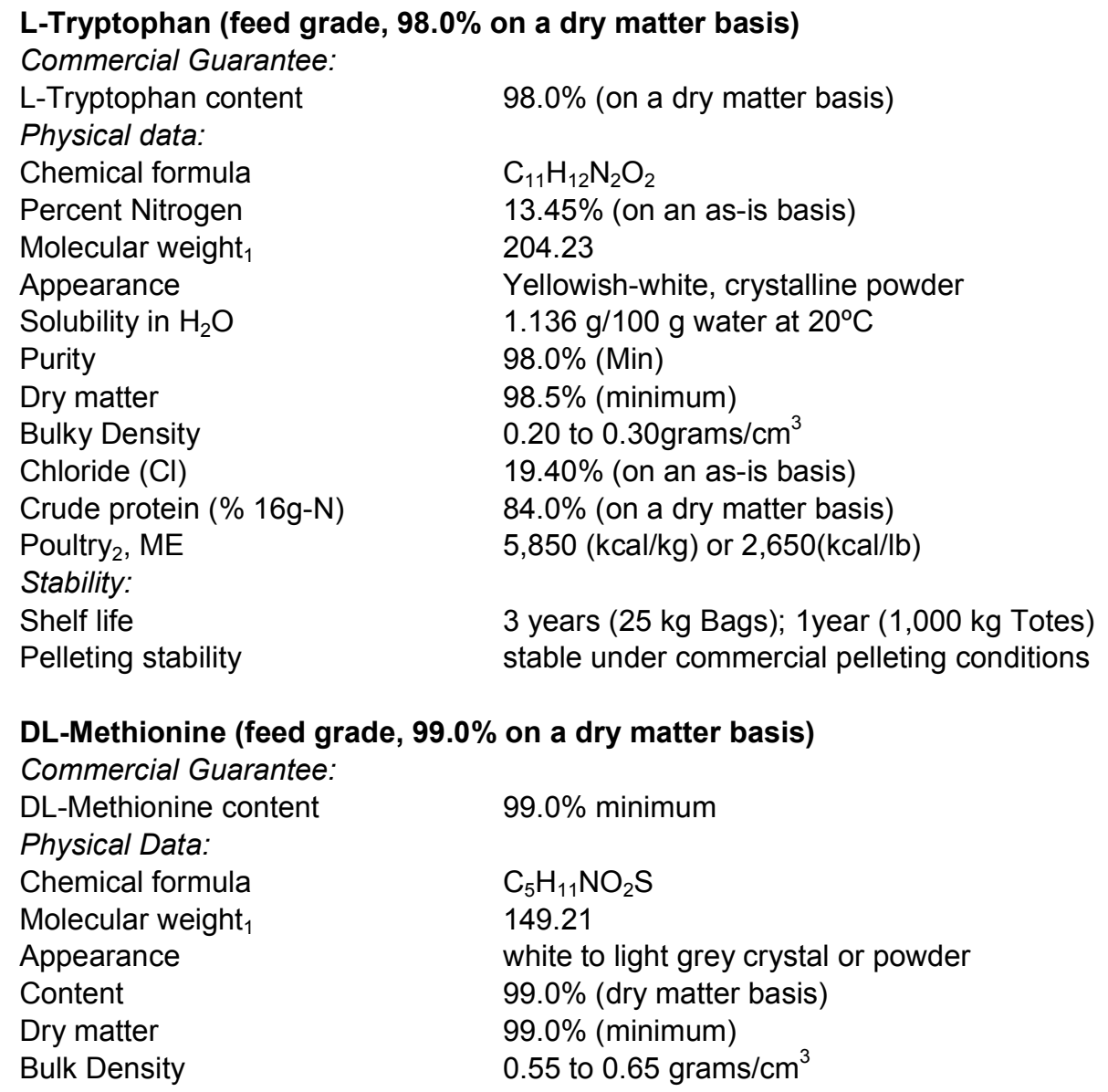

\subsection{Experimental Diets}

The feed ingredients used in ration formulation were purchased locally from a reputable commercial feed miller. Feed-grade amino acids were sourced as previously discussed. The experimental diets were compounded and manually mixed on the clean floor of the Poultry Section of the Teaching \& Research Farm. The experimental diets are presented in Table 1 . The dietary treatments were made up of the control diet 1 which had an approximate value of $23.0 \%$ crude protein of both plant and animal (fish meal) origins with a substantial supplementation of DLMethionine and L-Lysine. Diet 2also had 23.0\% all of plant origin with four most limiting EAAs. Diets 3, 4, 5 and 6 contained reduced inclusion levels of crude protein of plant origin at approximate values of $20.0 \%, 17.0 \%, 14.0 \%$ and $11.0 \%$, respectively. In essence, crude protein was reduced by 3 points across the diets from diet 3 to diet 6 . The four most limiting essential amino acids [7] in broilers were supplemented as required in the low crude protein diets.

\subsection{Management of Experimental Birds}

Two sets of three hundred broiler chicks were collected from reputable hatchery and two hundred and eighty eight were randomly picked after sexing on the 3rd day of the chicks for the experiment [8]. The chicks were brooded in a brooder house using electricity supplied constantly by $1 \mathrm{KVA}$ stand-by power generating plant at the Ekiti State University Teaching and Research Farms. During the first week of the broiler starter phase, the chicks were fed on commercial chicks mash containing $23 \%$ crude protein (CP) before the commencement of the experiment. The chicks were managed on the floor for this phase of experiment. Appropriate veterinary routines were observed from day old.

\subsection{Experimental Design}

Two hundred and eighty eight (288) broilers chicks were randomly assigned into 6 experimental treatments using a completely randomized design (CRD). The 6 treatments 
were replicated 4 times and each replicate contained 12 birds. The average weights of birds in each replicate were taken and carefully balanced to ensure uniformity of weights in all treatments.

\subsection{Nitrogen Determination}

Four birds were randomly selected (2 males and 2 females) such that at least a bird comes from each replicate/treatment 5 days before the termination of the experiment to determine the nitrogen retention of birds on each diet. These birds were transferred into metabolic cages where the excreta could be collected for analyses. Estimation of nitrogen retention, apparent nitrogen digestibility and 'operative' protein efficiency ratio were calculated. Total excreta voided during the last 5 days were collected, weighed, dried at $65-70^{\circ} \mathrm{C}$ in an air circulating oven for $72 \mathrm{~h}$ and preserved while the corresponding feed consumed was also recorded for nitrogen studies. The nitrogen contents of the samples were determined [9]. Nitrogen retained was calculated as the algebraic difference between nitrogen intake and faecal nitrogen (on dry matter basis) for the period. Apparent nitrogen digestibility was computed by expressing the nitrogen retained as a fraction of the nitrogen intake multiplied by 100 . The protein efficiency ratio was calculated as the ratio of weight gain to total protein.

\subsection{Statistical Analysis}

Data collected were subjected to analysis of variance (ANOVA) and means among treatments were separated accordingly using Computer Minitab Statistical Package (Version 16) [10].

\section{RESULTS AND DISCUSSION}

\subsection{Growth Performance}

The results obtained for the growth performance of broiler starter birds (1-28days) is presented on Table 2.

The average feed intake (FI) varied significantly $(P<0.05)$ from the highest value of $58.68 \pm 0.03 \mathrm{~g} / \mathrm{b} / \mathrm{d}$ obtained for the birds on the control diet (diet 1 ) 1 to $44.18 \pm 0.10 \mathrm{~g} / \mathrm{b} / \mathrm{d}$ obtained for birds on the $11 \%$ crude protein (CP) diet with essential amino acids supplementation (diet 6). The feed intake reduced significantly $(P<0.05)$ across the diets with the highest value obtained for birds on the control diet and the lowest $\mathrm{FI}$ value obtained for birds on $11 \% \mathrm{CP}$ diet with essential amino acids supplementation (diet 6).

The average weight gain (WG) also had the highest value of $33.47 \pm 0.03 \mathrm{~g} / \mathrm{b} / \mathrm{d}$ for birds on the conventional control diet with the minimum lysine acid methionine supplementation. Birds on diet 3 $(20.0 \% \mathrm{CP})$ had the average WG value of $29.65 \pm 0.25 \mathrm{~g} / \mathrm{b} / \mathrm{d}$ next to the highest value obtained for birds on diet 1. Birds on the least CP inclusion of $11.0 \%$ (diet 6 ) had the lowest average WG of $13.35 \pm 0.87 \mathrm{~g} / \mathrm{b} / \mathrm{d}$. There were significant variations $(\mathrm{P}<0.05)$ among all the average WG values.

The feed conversion ratio (FCR) had the best and lowest value of $1.75 \pm 0.01$ for birds on the control diet and the lowest for birds on the $11.0 \%$ $\mathrm{CP}$ (diet 6) at $3.31 \pm 0.20$. The FCR values of $2.15 \pm 0.03$ and $2.24 \pm 0.02$ obtained for birds on $23.0 \% \mathrm{CP}$ and $14.0 \% \mathrm{CP}$, respectively were similar $(P>0.05)$. The FCR of $1.90 \pm 0.02$ for birds on $20.0 \% \mathrm{CP}$ was also similar $(P>0.05)$ to the FCR obtained for birds on the control diet and FCR value of $2.05 \pm 0.01$ obtained for birds on $17.0 \%$ CP diet (diet 4).

The protein efficiency ratio (PER) had the best and highest value of $3.23 \pm 0.06$ for birds on the $14.0 \%$ (diet 5 ) and the lowest value of $2.05 \pm 0.12$ for birds on $23.0 \%$ CP diet (diet 2).

The significant variation $(P<0.05)$ of the average feed intake $(F I)(P<0.05)$ from the highest value of $58.68 \pm 0.03 \mathrm{~g} / \mathrm{b} / \mathrm{d}$ obtained for the birds on the control diet (diet 1 ) to $44.18 \pm 0.10 \mathrm{~g} / \mathrm{b} / \mathrm{d}$ obtained for birds on the $11 \%$ crude protein (CP) diet with essential amino acids supplementation (diet 6 ) is remarkable. The control diet was formulated with protein of both plant and animal origins and was ensured to meet the nutrient requirements [7] of the broiler starter chickens. Amino acid supplementation was restricted to the minimum conventional requirements for methionine and lysine supplementation at broiler starter phase of production. The feed intake reduced significantly $(P<0.05)$ across the diets with the highest value obtained for birds on the control diet and the lowest FI value obtained for birds on the least $\mathrm{CP}$ diet $(11 \% \mathrm{CP})$ even with adequate essential amino acids supplementation. There are conflicting literatures on the feed intake of broiler birds at starter phase. A relatively old literature in which responses of broiler chicks at 7-21 days to low protein diets supplemented with synthetic amino acids were measured indicated that body 
weight gain and feed efficiency, but not feed intake, were depressed by lowering CP content [11]. Also in the same league are the more recent works $[3,12]$ where it was found that chicks fed the lowest-CP diets consumed more feed. However, some other studies on low protein diets for broilers [13] showed depressed feed intake and was reported as the negative effect of low crude protein (LCP).

There were significant variations $(P<0.05)$ among all the average WG values. The average weight gain (WG) with the highest value of $33.47 \pm 0.03 \mathrm{~g} / \mathrm{b} / \mathrm{d}$ being for birds on the conventional control diet with the minimum lysine and methionine supplementation and the lowest WG of $13.35 \pm 0.87 \mathrm{~g} / \mathrm{b} / \mathrm{d}$ being for birds on the least dietary CP of $11.0 \%$. The feed conversion ratio (FCR) also had similar result with the best and lowest value of $1.75 \pm 0.01$ for birds on the control diet and the lowest for birds on the $11.0 \%$ $\mathrm{CP}$ at $3.31 \pm 0.20$. However, the FCR of $1.90 \pm 0.02$ for birds on $20.0 \%$ CP (with essential amino acids supplementation) was also similar ( $P>$ 0.05 ) to the FCR obtained for birds on the control diet and FCR value of $2.05 \pm 0.01$ obtained for birds on $17.0 \%$ CP (with essential amino acids supplementation). The FCR values of $2.15 \pm 0.03$ and $2.24 \pm 0.02$ obtained for birds on $23.0 \% \mathrm{CP}$ (with essential amino acids supplementation) and $14.0 \%$ CP (with essential amino acid supplementation), respectively were similar $(P>0.05)$.

The variations in the WG and FCR values for the broiler starter phase of production can best be explained by the several corroborative studies $[3,4,14,15,16,17]$. It has been reported that chickens fed low-protein feeds, despite having enough of each essential amino acid (to support excellent growth), failed to thrive and were excessively fat. It was realized that chickens require the essential amino acids plus some other amount of nonessential amino acids to synthesize protein at acceptable rates [17]. Therefore, it was clear that chickens require not only the essential amino acids but also some other quantity of amino acids, which have been referred to as the "nonessential" amino acids. Clearly, some quantity of these nonessential amino acids is needed (essential) for growth. The sum of the essential and nonessential amino acids may also be referred to as the $\mathrm{CP}$ requirement. The $1994 \mathrm{NRC}$, for instance, set the $\mathrm{CP}$ requirement for 0 - to 3 -wk-old broilers at $23 \%$.
The fact that the FCR of birds on the $17.0 \%$ CP diet with essential amino acids supplementation were still similar $(P>0.05)$ to the $F C R$ values obtained for birds on $23.0 \%$ and $20.0 \%$ CP diets with essential amino acids supplementation disagreed with previous work where data suggest that after the starter period, reducing dietary CP to $90 \%$ of the recommended values had no detrimental impact on broiler performance [18]. Data from the present result indicated that $\mathrm{CP}$ can equally be reduced with about 3 points from conventional recommendation [7] without adverse effect on the growth parameters that were investigated in this study. The assumption here is that higher crystalline amino acids content of diet may result in better amino acid availability and better performance because it is assumed that the availability of free crystalline amino acid is higher than that of amino acids in intact proteins. The protein efficiency ratio (PER) had the best and highest value of $3.23 \pm 0.06$ for birds on the $14.0 \%$ (diet 5 ) and the lowest value of $2.05 \pm 0.12$ for birds on $23.0 \%$ CP diet (diet 2).

\subsection{Nitrogen Utilization}

The nitrogen utilization of chicks fed varying crude protein levels with amino acids supplementation at broiler starter phase (1-28 days) is presented in Table 3.

The average nitrogen intake (NI) had the highest significant $(P<0.05)$ value for birds on the control diet at $2.17 \pm 0.01 \mathrm{gN}$ and lowest $(P<0.05)$ for birds on the $11.0 \% \mathrm{CP}$ diet (diet 6) at $0.80 \pm 0.02 \mathrm{gN}$. There was a consistent reduction in the average $\mathrm{NI}$ values from birds on the control diet to the birds on the diet with the least crude protein of $11.0 \%$. The nitrogen in droppings had similar $(P>0.05)$ values ranging from $0.02 \mathrm{gN}$ to $0.04 \mathrm{gN}$. The average nitrogen retention (NR) had the highest significant value of $0.78 \pm 0.02 \mathrm{gN}$ for birds on the $11.0 \% \mathrm{CP}$ diet (diet 6 ).

The Apparent Nitrogen Digestibility (AND) values were similar $(P>0.05)$ for birds on the control diet, diet $2(23.0 \%$ CP minimum amino acids supplementation and diet $3(20.0 \%$ CP $)$ at $75.70 \pm 0.11 \%, 76.64 \pm 0.065 \%$ and $75.10 \pm 0.03 \%$, respectively. The lowest significantly different $(P<0.05)$ AND value of $45.65 \pm 0.79 \%$ was obtained for birds on $11.0 \%$ CP diet (diet 6).

The average nitrogen intake $(\mathrm{NI})$ expectedly had the highest significant $(P<0.05)$ value for birds on the control diet at $2.17 \pm 0.01 \mathrm{gN}$ and lowest $(P<0.05)$ for birds on the $11.0 \%$ CP diet (diet 6$)$ 
at $0.80 \pm 0.02 \mathrm{gN}$. The consistent reduction in the average $\mathrm{NI}$ values from birds on the control diet to the birds on the diet with the least crude protein of $11.0 \%$ was consistent with the average feed intake by experimental birds on each dietary treatment. Since the feed intake was significantly impeded for the low crude protein diets, it was expected that nitrogen intake would also be reduced. However, the similarity $(P>0.05)$ in the nitrogen in droppings among all experimental birds ranging from $0.02 \mathrm{gN}$ to $0.04 \mathrm{gN}$ and the highest nitrogen retention value of $0.78 \pm 0.02 \mathrm{gN}$ obtained for birds on the least crude protein diet of $11.0 \% \mathrm{CP}$ called for attention. It has been earlier reported [19] that CP retention increased from 35 to $43 \% \quad(P<0.05)$ and that actual $C P$ excreted increased from 293 to $317 \mathrm{~g} / \mathrm{kg}$ $(P>0.05)$ corroborated this recent finding. It was inferred that the increased gut microflora as the bird matures and the efficiency of nitrogen and other nutrients (eg., starch and fiber) utilization at different stages of development might have been responsible for this result [19].

The Apparent Nitrogen Digestibility (AND) values were similar $(P>0.05)$ for birds on the control diet, diet $2(23.0 \%$ CP minimum amino acids supplementation and diet $3(20.0 \% \quad \mathrm{CP})$ at $75.70 \pm 0.11 \%, 76.64 \pm 0.065 \%$ and $75.10 \pm 0.03 \%$, respectively. The lowest significantly different $(P<0.05)$ AND value of $45.65 \pm 0.79 \%$ was obtained for birds on $11.0 \%$ CP diet (diet 6).It has been postulated that the higher crystalline amino acids content of diet may result in better amino acid availability [18] and consequently, the better protein efficiency ratio obtained for some experimental chicks in on very low crude protein diets. It is also ascertained that the availability of free crystalline amino acid is higher than that of amino acids in intact proteins.

Table 1. Experimental diets for chicks fed varying crude protein levels with amino acids supplementation at broiler starter phase (1 - 28 days)

\begin{tabular}{|c|c|c|c|c|c|c|}
\hline \multirow[t]{3}{*}{ Ingredients } & \multirow{3}{*}{$\begin{array}{l}\text { Control } \\
\text { diet } 1\end{array}$} & \multicolumn{5}{|c|}{ Crude protein reduction/Amino acids supplementation } \\
\hline & & Diet 2 & Diet3 & Diet 4 & Diet 5 & Diet 6 \\
\hline & & $23.0 \% \mathrm{CP}$ & $20.0 \% \mathrm{CP}$ & $17.0 \% \mathrm{CP}$ & $14.0 \% \mathrm{CP}$ & $11.0 \% \mathrm{CP}$ \\
\hline Maize $(11 \% \mathrm{CP})$ & 56.4 & 56.7 & 56.7 & 56.7 & 56.7 & 56.7 \\
\hline $\begin{array}{l}\text { Soyabean meal }(45 \% \\
\text { CP) }\end{array}$ & 36.0 & 39.0 & 32.0 & 25.0 & 18.0 & 11.0 \\
\hline Fish meal $(72 \% \mathrm{CP})$ & 3.0 & - & - & - & - & - \\
\hline Rice husk & - & - & 5.0 & 5.0 & 11.0 & 16.0 \\
\hline Palm oil & - & - & 2.0 & 5.0 & 6.0 & 8.0 \\
\hline Bone meal & 2.5 & 2.5 & 2.5 & 2.5 & 2.5 & 2.5 \\
\hline Oyster shell & 1.0 & 1.0 & 1.0 & 1.0 & 1.0 & 1.0 \\
\hline Salt & 0.3 & 0.3 & 0.3 & 0.3 & 0.3 & 0.3 \\
\hline${ }^{* *}$ Premix & 0.5 & 0.5 & 0.5 & 0.5 & 0.5 & 0.5 \\
\hline \multicolumn{7}{|c|}{ Amino acid supplementation } \\
\hline Lysine & 0.15 & 1.5 & 1.5 & 1.5 & 1.5 & 1.5 \\
\hline Methionine & 0.15 & 1.0 & 1.0 & 1.0 & 1.0 & 1.0 \\
\hline Threonine & - & 1.0 & 1.0 & 1.0 & 1.0 & 1.0 \\
\hline Trytophan & - & 0.5 & 0.5 & 0.5 & 0.5 & 0.5 \\
\hline \multicolumn{7}{|c|}{ Calculated composition } \\
\hline Crude Protein, \% & 23.3 & 23.0 & 19.8 & 16.6 & 13.7 & 10.8 \\
\hline${ }^{*} \mathrm{ME}(\mathrm{Kcal} / \mathrm{Kg})$ & 2893.3 & 2889.7 & 2884.0 & 2960.1 & 2872.5 & 2866.8 \\
\hline Crude Fibre, \% & 3.9 & 4.1 & 3.8 & 3.4 & 7.4 & 9.0 \\
\hline Fat, \% & 3.8 & 3.6 & 3.5 & 3.3 & 3.1 & 2.9 \\
\hline \multicolumn{7}{|c|}{ Proximate composition } \\
\hline Crude Protein & 23.1 & 23.3 & 18.9 & 16.9 & 14.2 & 11.3 \\
\hline Crude Fibre, \% & 3.9 & 4.1 & 3.8 & 3.4 & 7.4 & 9.0 \\
\hline Fat, \% & 3.8 & 3.6 & 3.5 & 3.3 & 3.1 & 2.9 \\
\hline $\mathrm{MC}, \%$ & $9.35 \pm 0.08$ & $9.42 \pm 0.04$ & $9.46 \pm 0.06$ & $9.43 \pm 0.03$ & $9.36 \pm 0.06$ & $9.34 \pm 0.05$ \\
\hline $\begin{array}{r}{ }^{\star} M E, \text { metabolizable ener } \\
\text { E(35,000iu);K(1,900mg); } \\
\text { acid(11,000mg); Nicotinic } \\
\text { Mn(64,000mg); Z } \\
\text { Choline }(475,00\end{array}$ & $\begin{array}{l}=(0.860+0 . \\
12(19 m g) ; R i \\
c i d(45,000 m g \\
40,000 m g) ; F \\
\text { mg); Methioni } \\
\text { CP: }\end{array}$ & $\begin{array}{l}29(\mathrm{GE}-0.78 \mathrm{C} \\
\text { oflavin }(7,000 \\
\text {; Folic acid } 1 \\
(32,000 \mathrm{mg}) ; \\
\text { e(50,000mg); }\end{array}$ & $\begin{array}{l}\text { [20] }{ }^{*} \text { Contail } \\
\text { g); Pyridoxine } \\
\text { 00mg); Biotin } \\
\text { (160mg); } I_{2}(8\end{array}$ & $\begin{array}{l}\text { ed vitamins } A \\
\text { 3,800mg); Th } \\
\text { 113mg); and } \\
\text { Omg); and ott } \\
\text { and Spiramyc } \\
\text { d Energy }\end{array}$ & $\begin{array}{l}0,000,000 i u) ; \\
\text { mine }(2,200 \mathrm{mg} \\
\text { ce elements } \\
\text { r items as Co } \\
(5,000 \mathrm{mg}) \text { per }\end{array}$ & $\begin{array}{l}\text { (2,000,000iu); } \\
\text { D Panthotenic } \\
\text { Cu(8,000mg); } \\
\text { o0mg); } \\
.5 \mathrm{~kg}\end{array}$ \\
\hline
\end{tabular}


Table 2. Performance of chicks fed varying crude protein levels with amino acids supplementation at starter phase (1 - 28 days)

\begin{tabular}{lllllll}
\hline Parameters & \multirow{2}{*}{$\begin{array}{l}\text { Control diet } \\
\mathbf{2 3 . 0 \%} \text { CP }\end{array}$} & \multicolumn{4}{c}{ Crude protein reduction/Amino acids supplementation } \\
\cline { 3 - 6 } & & Diet 2 & Diet 3 & Diet 4 & Diet 5 & Diet 6 \\
\cline { 3 - 6 } & $\mathbf{2 3 . 0 \%} \mathbf{C P}$ & $\mathbf{2 0 . 0 \%} \mathbf{C P}$ & $\mathbf{1 7 . 0 \%} \mathbf{C P}$ & $\mathbf{1 4 . 0 \%} \mathbf{C P}$ & $\mathbf{1 1 . 0 \%} \mathbf{C P}$ \\
\hline $\begin{array}{l}\text { Av. feed intake, } \\
\text { g/b/d }\end{array}$ & $58.68 \pm 0.03^{\mathrm{a}}$ & $55.48 \pm 0.04^{\mathrm{c}}$ & $56.11 \pm 0.06^{\mathrm{b}}$ & $54.51 \pm 0.09^{\mathrm{d}}$ & $51.35 \pm 0.13^{\mathrm{e}}$ & $44.18 \pm 0.10^{\dagger}$ \\
$\begin{array}{l}\text { Av. weight gain, } \\
\text { g/b/d }\end{array}$ & $33.47 \pm 0.03^{\mathrm{a}}$ & $25.73 \pm 0.32^{\mathrm{d}}$ & $29.65 \pm 0.25^{\mathrm{b}}$ & $26.63 \pm 0.11^{\mathrm{c}}$ & $22.90 \pm 0.16^{\mathrm{e}}$ & $13.35 \pm 0.87^{\mathrm{f}}$ \\
$\begin{array}{l}\text { Feed conversion } \\
\text { (feed/gain) }\end{array}$ & $1.75 \pm 0.01^{\mathrm{e}}$ & $2.15 \pm 0.03^{\mathrm{bc}}$ & $1.90 \pm 0.02^{\mathrm{de}}$ & $2.05 \pm 0.01^{\mathrm{cd}}$ & $2.24 \pm 0.02^{\mathrm{b}}$ & $3.31 \pm 0.20^{\mathrm{a}}$ \\
$\begin{array}{l}\text { Protein efficiency } \\
\text { (PER) }\end{array}$ & $2.49 \pm 0.01^{\mathrm{d}}$ & $2.05 \pm 0.12^{\mathrm{e}}$ & $2.65 \pm 0.02^{\mathrm{c}}$ & $2.84 \pm 0.04^{\mathrm{b}}$ & $3.23 \pm 0.06^{\mathrm{a}}$ & $2.47 \pm 0.06^{\mathrm{d}}$ \\
\hline
\end{tabular}

a, b, c, Means within a row with different superscript are significantly different $(P<0.05)$

Table 3. Nitrogen utilization of chicks fed varying crude protein levels with amino acids supplementation at broiler starter phase (1 - 28 days)

\begin{tabular}{|c|c|c|c|c|c|c|}
\hline \multirow[t]{3}{*}{ Parameters } & \multirow{3}{*}{$\begin{array}{l}\text { Control diet } \\
23.0 \% \text { CP }\end{array}$} & \multicolumn{5}{|c|}{ Crude protein reduction/Amino acids supplementation } \\
\hline & & Diet 2 & Diet 3 & Diet 4 & Diet 5 & Diet 6 \\
\hline & & $23.0 \% \mathrm{CP}$ & $20.0 \% \mathrm{CP}$ & $17.0 \% \mathrm{CP}$ & $14.0 \% \mathrm{CP}$ & $11.0 \% \mathrm{CP}$ \\
\hline $\begin{array}{l}\text { Nitrogen intake } \\
\text { (gN/bird/day) }\end{array}$ & $2.17 \pm 0.01^{\mathrm{a}}$ & $2.06 \pm 0.03^{b}$ & $1.80 \pm 0.01^{\mathrm{c}}$ & $150 \pm 0.02^{\mathrm{d}}$ & $1.16 \pm 0.02^{\mathrm{e}}$ & $0.80 \pm 0.02^{f}$ \\
\hline $\begin{array}{l}\text { Nitrogen in } \\
\text { droppings } \\
\text { (gN/bird/day) }\end{array}$ & $0.04 \pm 0.01$ & $0.04 \pm 0.00$ & $0.02 \pm 0.00$ & $0.02 \pm 0.00$ & $0.03 \pm 0.01$ & $0.02 \pm 0.00$ \\
\hline $\begin{array}{l}\text { Nitrogen retention } \\
\text { (gN/bird/day) }\end{array}$ & $2.14 \pm 0.01^{\mathrm{a}}$ & $2.02 \pm 0.01^{b}$ & $1.79 \pm 0.03^{c}$ & $1.47 \pm 0.01^{d}$ & $1.13 \pm 0.01^{\mathrm{e}}$ & $0.78 \pm 0.02^{f}$ \\
\hline $\begin{array}{l}\text { Apparent nitrogen } \\
\text { Dig. (\%) }\end{array}$ & $75.70 \pm 0.11^{\mathrm{a}}$ & $76.64 \pm 0.65^{a}$ & $75.10 \pm 0.03^{\mathrm{a}}$ & $59.65 \pm 0.79^{b}$ & $56.25 \pm 0.21^{c}$ & $45.65 \pm 0.79^{d}$ \\
\hline
\end{tabular}

\section{CONCLUSION}

The growth parameters for birds on conventional control diet in which $23.0 \% \mathrm{CP}$ was used with an animal protein source and the growth parameters for growing birds on $20.0 \%$ CP with EAAs supplementation had the best similar FCR. Therefore crude protein can be reduced by 3 percentage points from the conventional $23.0 \%$ (NRC 1994 recommendation) to $20.0 \%$ CP without any detrimental effects on the growth performance indices of broiler starter birds (1-28 days). Protein efficiency ratios were better for growing birds on EAAs supplementation.

\section{ACKNOWLEDGEMENT}

We gratefully acknowledge the funding of the current research studies by the Tertiary Education Trust Fund (TETFUND) Reference Number: AD/ORD/43/TET/VOL 1/077.

\section{COMPETING INTERESTS}

Authors have declared that no competing interests exist.

\section{REFERENCES}

1. Parr JF, Summers JD. The effects of minimizing amino acid excesses in broiler diets. Poult. Sci. 1991;70:1540-1549.

2. Moran ET,Stilborn B. Effect of glutamic acid on broiler given sub-marginal crude protein with adequate essential amino acids using feeds high and low in potassium. Poult Sci. 1996;75:120-129.

3. Aletor VA, Hamid II, Nieb E, Pfeffer E. Low-protein amino acid-supplemented diets in broiler chickens: Effects on performance, carcass characteristics, whole-body composition and efficiencies of nutrient. Journal of the Science of Food and Agriculture. 2000;80:547-554.

4. Bregendahl K, Sell JL, Zimmerman DR. Effect of low-protein diets on growth performance and body composition of broiler chicks. The Journal of Applied Poultry Research. 2002;81(8):1156-1167.

5. Sterling KG, Vedenov DV, Pesti GM, BakalliRI. Economically optimal dietary crude protein and lysine levels for starting broiler chicks. Poult. Sci. 2005;84:29-36. 
6. Waldroup PW, Jiang Q, Fritts CA. Effect of supplementing broiler diets low in crude protein with essential and nonessential amino acids. Intr. J. Poult. Sci. 2005;4:425431.

7. NRC. Nutrient requirements of poultry. $9^{\text {th }}$ Rev. Ed. Natl. Acad. Press, Washington, DC; 1994.

8. Laseinde EAO, Oluyemi JA. Sexual dimorphism in the growth pattern of broiler under different dietary and housing conditions. Nig. J. Anim. Prod. 1997;24:16.

9. AOAC. Association of Official Analytical Chemistry. Official Methods of Analysis 19th edition Washington D; 2010.

10. Minitab Statistical Package (ver. 16): Available:https://www.minitab.com/en-us/

11. Pinchasov $\mathrm{Y}$, Mendonca CX, Jensen LS. Broiler chick response to low protein diets supplemented with synthetic amino acids. Poultry Science. 1990;69(11):1950-1955.

12. Kamran Z, Sarwar $M$, Nisa $M$, Nadeem MA, Mahmood S, Babar§ ME, Ahmed S. Effect of low-protein diets having constant energy-to-protein ratio on performance and carcass characteristics of broiler chickens from one to thirty-five days of age. Poultry Science. 2008;87(3):468-474.

DOI: $10.3382 / p s .2007-00180$

13. Aftab U, Ashraf M. Jiang Z. Low protein diets for broilers. World's Poultry Science Journal. 2006;62(4):688-701.

14. Aviagen. Broilers, Protein and Profit. Ross Tech. 2000; 00/39. Aviagen, Newbridge, Midlothian, Scotland, UK.
15. Brooks SE, Allen HM, Firman JD. Utilization of low crude protein diets fed to 0-3 wk broilers. Poult. Sci. 2003;82(1):37. (Abstr.)

16. Corzo A, Fritts CA, Kidd MT, Kerr BJ. Response of broiler chicks to essential and non-essential amino acid supplementation of low crude protein diets. Animal Feed Science and Technology. 2005;118(3\&4): 319-327.

17. Pesti GM. Impact of dietary amino acid and crude protein levels in broiler feeds on biological performance. J Appl Poult Res. 2009;18(3):477-486. doi: 10.3382/japr.2008-00105

18. Abbasi MAl, Mahdavi AHI, Samie AHI, Jahanian RI. Effects of different levels of dietary crude protein and threonine on performance, humoral immune responses and intestinal morphology of broiler chicks. Revista Brasileira de Ciência Avícola. vol.16 no.1 Campinas Jan./Mar. 2014. DOI:http://dx.doi.org/10.1590/S1516635X2014000100005

19. Scott TA. The influence of dietary fat source and level, diet dilution and early feed restriction on gross energy metabolizability and crude protein retention by broiler chicks from 0 to 35 days of age. Can. J. Animal Science; 1992. (in press).

20. Campbell GL, Salmon RE, Classen HL. Prediction of metabolizable energy of broiler diets from chemical analysis. Poultry Science. 1986;65(11):2126-2134. DOI:https://doi.org/10.3382/ps.0652126

(c) 2017 Fasuyi et al.; This is an Open Access article distributed under the terms of the Creative Commons Attribution License (http://creativecommons.org/licenses/by/4.0), which permits unrestricted use, distribution, and reproduction in any medium, provided the original work is properly cited.

Peer-review history:

The peer review history for this paper can be accessed here: http://sciencedomain.org/review-history/21389 